\title{
Bacteriological examination of pus from abscesses of the central nervous system
}

\author{
JOHN DE LOUVOIS \\ From the Department of Microbiology, Queen Charlotte's Hospital for Women, Goldhawk Road, \\ London W6 OXG, UK
}

SUMMARY The methods used successfully to examine pus from abscesses of the central nervous system are described. The association between direct inoculation of intracranial pus into a liquid anaerobic culture medium and the isolation of viable bacteria is emphasised. Cultural methods for the recognition of the streptococci associated with brain abscess and methods for the assay of antimicrobial drugs in pus are presented. The role of gas liquid chromatography is discussed.

Pus from brain abscesses and from subdural and extradural empyemata of the brain and spinal cord has been reported as sterile in up to $60 \%$ of cases in published series (Kao, 1973; see review of de Louvois (1978)). Bacteria have sometimes been seen in Gram-stained films but have failed to grow on culture (Shaw and Russell, 1975). If meticulous attention is paid to microbiological technique, bacteria can be cultured from all abscesses on primary investigation. Ingham et al. (1977) recorded positive cultures from nine consecutive abscesses and de Louvois et al. (1977a) from 46 studied.

This report details the microbiological procedures that afford the best chance of culturing bacteria irom abscesses of the central nervous system.

\section{Material and methods}

For satisfactory results the pus must be inoculated with a minimum of delay, and it is important that examining laboratories realise that brain abscess is no less an emergency for the laboratory than it is for the neurosurgeon. Ideally, the bacteriologist should be on hand when the abscess is tapped in the operating room. If this is not possible or feasible, precise instructions should be issued to the neurosurgical team so that the pus may be inoculated on to suitable media as soon as it has been aspirated and the specimens transported to the examining laboratory as rapidly as possible.

Received for publication 29 August 1979

\section{EXAMINATION FOR BACTERIA}

\section{Transport of samples}

Should there be risk of delay, the specimen should be divided, one aliquot being placed into an anaerobic liquid medium (thioglycollate or thiol broth) containing $\beta$-lactamase (Whatman) and the other into a suitable sterile, screw-capped container. Samples should be sent to the examining laboratory so as to reach it in the shortest possible time and should ideally be transported at $4^{\circ} \mathrm{C}$. This can be done most satisfactorily by means of a freezable sachet (Freezella-Raven Scientific) in a suitable container.

Direct inoculation of plates and liquid media for the cultivation of microorganisms

The following media should be inoculated from the thioglycollate $/ \beta$-lactamase broth:

$16 \%$ horse blood agar incubated aerobically;

$26 \%$ horse blood agar incubated anaerobically;

$36 \%$ horse blood agar containing $0.01 \%$ neomycin

(Upjohn) incubated anaerobically;

4 chocolated blood agar incubated in $10 \%$ carbon dioxide.

Direct antibiotic sensitivity tests should be set up on chocolated blood agar and incubated anaerobically and in $10 \%$ carbon dioxide. The anaerobic environment should contain $10 \%$ carbon dioxide.

Plates are incubated for up to five days at $35^{\circ} \mathrm{C}$, during which time they are examined daily. Individual colonies are filmed and subcultured for identity and antibiotic sensitivity using standard microbiological procedures (see below). Primary sensitivity of the infecting organisms is determined to penicillin, ampicillin, chloramphenicol, co-trimoxazole, clin- 
damycin, streptomycin, and metronidazole, for these are the antibiotics most frequently used in the treatment of brain abscess. Staphylococci are also tested against cloxacillin and fusidic acid.

The thioglycollate broth is incubated for 48 hours and subcultured to the range of media above, irrespective of the culture results already obtained.

\section{BLOOD CULTURE}

Blood for culture taken at the time of aspiration of pus should be inoculated into $0 \cdot 1 \%$ dextrose digest broth containing added $p$-aminobenzoic acid and $\beta$-lactamase. Subcultures should be made after 1,2 , 3,7 , and 14 days' incubation at $35^{\circ} \mathrm{C}$ on to blood agar plates incubated aerobically and anaerobically and chocolated blood agar incubated in $10 \%$ carbon dioxide.

IDENTIFICATION OF BACTERIA

The bacteria commonly isolated from intracranial and intraspinal abscesses are listed in Table 1.

Table 1 Bacteria commonly isolated from intracranial and intraspinal abscesses

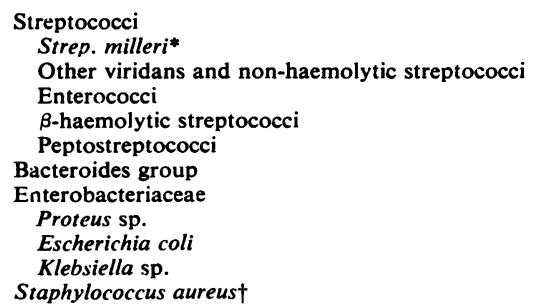

* Most frequent organism isolated from intracranial pus

†Associated with post-traumatic and spinal lesions

Routine bacteriological procedures based on the methods and nomenclature of Cowan and Steel (1965) can be used to identify aerobic isolates other than the viridans streptococci. Anaerobic Gramnegative rods can be identified initially by antibiotic sensitivity tests (Leigh, 1976) and subsequently by the API 20 A test kit, which is also of value in identifying anaerobic cocci. Organisms of the bacteroides group when present in intracranial pus often occur as a mixed population.

The identification methods used for the viridans and non-haemolytic streptococci are, in general, those described by Colman (1970), and organisms should be classified according to the scheme proposed by Colman (1970) and Colman and Williams (1972). In cases of doubt the organisms should not be allocated specific status.
CULTURAL METHODS FOR CHARACTERISING STREPTOCOCCI

Acid production from glucose mannitol arabinose, lactose, sucrose, trehalose, raffinose, salicin, inositol, and sorbitol is tested in phenol red peptone water with $20 \%$ horse serum. Cultures are incubated in $10 \%$ carbon dioxide $\left(\mathrm{CO}_{2}\right)$ and examined after one, two, and seven days. Hydrolysis of aesculin is tested on $0.1 \%$ aesculin agar containing $5 \%$ horse serum. Acetylmethyl carbinol production is determined by the method described by Poole and Wilson (1976) and hydrolysis of arginine by the method of Niven et al. (1942). The liberation of free ammonia is detected by adding $1 \mathrm{ml}$ of $1 / 10$ dilution of a sevenday arginine broth culture to a mixture consisting of $1 \mathrm{ml} 0.17 \mathrm{~mm}$ sodium nitroprusside in $0.106 \mathrm{M}$ phenol water and $1 \mathrm{ml} 0 \cdot 125 \mathrm{~N}$ sodium hydroxide in water containing $11 \mathrm{~mm}$ sodium hypochlorite. A positive reaction is demonstrated by production of a blue colour. Production of extracellular polysaccharide from sucrose is demonstrated after growth in the medium of Bailey and Oxford (1958) for five days by the method of Hehre and Neill (1946). Growth on media containing bile salts is demonstrated on a blood agar plate, one-half of which is removed and replaced with $10 \%$ or $40 \%$ bile salts in nutrient agar with $5 \%$ added horse serum. Strains are streak inoculated on to both halves of the plate and examined for growth after 48 hours' incubation at $37^{\circ} \mathrm{C}$. The biochemical reactions of the viridans and non-haemolytic streptozocci are shown in Table 2.

ANTIBIOTIC ASSAY

A number of factors affect the penetration and concentration of antimicrobial drugs in intracranial pus. It is therefore important, if antibiotics are to be used effectively in the management of brain abscess, that antibiotic concentration should be assayed whenever possible.

Samples of pus and serum can be assayed for the presence of antimicrobial drugs most satisfactorily by the plate diffusion technique. Thirty to forty millilitres of appropriate assay medium at $50^{\circ} \mathrm{C}$ is poured into a 6 in diameter petri dish (Sterilin) on a levelling tray. Once set the medium is dried and surface seeded with a dilution of a log phase broth culture of the indicator organism which results in semiconfluent growth after 18 hours' incubation. The inoculated medium is dried and stored at $4^{\circ} \mathrm{C}$ for use within three days. Before use wells are cut with a sterile cork borer. The wells are filled at random with test and standard solutions in duplicate. After prediffusion at $4^{\circ} \mathrm{C}$ for 1 hour, the plate is incubated at $37^{\circ} \mathrm{C}$ overnight $\left(30^{\circ} \mathrm{C}\right.$ for assay of cloxacillin). The log of the concentration of antibiotic standards is plotted against the inhibition 
Table 2 Biochemical characters of the viridans and non-haemolytic streptococci

\begin{tabular}{|c|c|c|c|c|c|}
\hline & Strep. milleri & Strep. mutans & Strep. mitior & Strep. sanguis & Strep. salivarius \\
\hline \multicolumn{6}{|l|}{ Acid production in: } \\
\hline Glucose & + & + & + & + & + \\
\hline Mannitol & - & + & - & - & - \\
\hline Arabinose & - & - & - & - & - \\
\hline Lactose & + & + & + & + & + \\
\hline Sucrose & + & + & + & + & + \\
\hline Trehalose & + & + & $\mathbf{v}$ & + & $\mathbf{v}$ \\
\hline Raffinose & - & + & $\mathbf{v}$ & $\mathrm{v}$ & $\mathbf{v}$ \\
\hline Salicin & - & + & $\mathbf{v}$ & + & + \\
\hline Inositol & - & + & - & + & $\mathbf{v}$ \\
\hline Sorbitol & - & + & - & - & - \\
\hline \multicolumn{6}{|l|}{ Hydrolysis of: } \\
\hline Aesculin & + & + & - & + & + \\
\hline Arginine & + & - & - & + & - \\
\hline Voges Proskauer & + & + & - & - & $\mathbf{v}$ \\
\hline Levan from sucrose & - & - & - & - & + \\
\hline Dextran from sucrose & - & + & - & + & - \\
\hline \multicolumn{6}{|l|}{ Growth on bile } \\
\hline $10 \%$ & $\mathbf{v}$ & $\mathrm{v}$ & - & - & $\mathrm{v}$ \\
\hline $\begin{array}{l}\quad 40 \% \\
\text { (Parker and Ball, 1976) }\end{array}$ & - & - & - & - & $\mathbf{v}$ \\
\hline
\end{tabular}

$\mathrm{v}=$ variable reaction

zone diameter in millimetres. The concentration in the test fluids is determined from the line of best fit drawn through the standard points. Table 3 gives essential details of assay systems that have been found satisfactory. The accuracy of plate diffusion assays is greatly increased if the zones are read on a zone reader.

The following factors should also be considered when undertaking antibiotic assay:

Avoidance of falsely low readings due to decay of antibiotics in transit

The laboratory should be notified during or immedi- ately after operation that pus has been located. Serum standards for the anticipated assay should be prepared as soon as the sample is collected and stored under identical or comparable conditions. This is especially necessary for the $\beta$-lactam antibiotics, which tend to be degraded in pus.

Separation and assay of serum

Samples of serum for assay should be separated from the blood clot immediately on arrival in the laboratory and stored with the prepared standards at $4^{\circ} \mathrm{C}$ or $-20^{\circ} \mathrm{C}$, depending on the anticipated delay before the assay is performed.

Table 3 Assay systems for the common antimicrobial drugs used in treatment

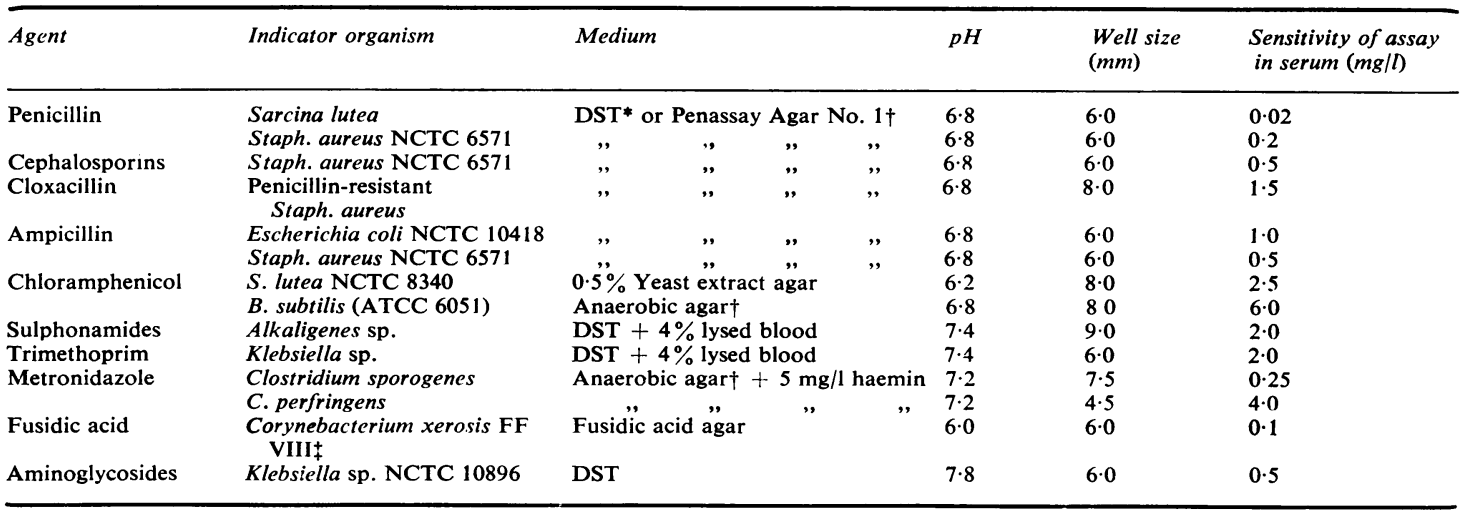

*Oxoid †Difco ‡Leo Laboratories 


\section{Liquefaction of pus}

Mucoid samples may be liquefied by adding $1 \mathrm{ml}$ pancreatin solution* to approximately $1 \mathrm{ml}$ pus and incubating the mixture at $37^{\circ} \mathrm{C}$ for 30 minutes. An accurate volumetric measurement of the pus can be made at the end of this time by the method of subtraction (de Louvois and Hurley, 1976).

Samples of pus that require pancreatin treatment are assayed in agar to which $1 \mathrm{ml}$ pancreatin solution had been added before pouring.

Pus samples that require pancreatin treatment are assayed against standards that have been similarly treated.

\section{ASSAY OF ANTIBIOTIC MIXTURES}

The procedures used to assay antimicrobial drugs in a mixture include the use of indicator organisms resistant to the unwanted drug, $\mathrm{pH}$ control of the assay system, use of variation in diffusion rates between different drugs, dilution of samples, and drug inactivation. The inactivators used are $\beta$ lactamase I, $\beta$-lactamase I and II, $p$-aminobenzoic acid, and thymidine. Aminoglycosides can be removed by treating samples with cellulose phosphate (Sigma) (Stevens and Young, 1977).

A further feature that complicates the assay of antimicrobial drugs in pus is that of inactivation. This most often affects $\beta$-lactamase sensitive penicillins in the presence of $\beta$-lactamase producing bacteria. However, the inactivation of some penicillins by purulent material alone and in the absence of $\beta$-lactamase or $\beta$-lactamase producing bacteria has been reported (de Louvois and Hurley, 1977).

\section{GAS LIQUID CHROMATOGRAPHY}

The presence of short and long chain fatty acids in samples of pus, cerebrospinal fluid, and broth cultures is highly indicative of anaerobic bacteria and can be demonstrated by gas-liquid chromatography (GLC). A Pye series 104, model 64, gas chromatograph with a glass column $5 \mathrm{ft}$ long and $4 \mathrm{~mm}$ internal diameter containing Chromosorb 101 , mesh $80 / 100$ (Field Instruments Ltd) which is not coated is a suitable system. Using this column, it is not necessary to extract or esterify the specimens. Samples of $1 \mu \mathrm{l}$ of crude material are injected directly on to a precolumn also packed with Chromosorb 101. The injection port is maintained at a temperature of $200^{\circ} \mathrm{C}$ while the flame ionisation detector should be at $240^{\circ} \mathrm{C}$. The carrier gas is nitrogen, at a flow rate of $40 \mathrm{ml}$ per minute, and the

*Pancreatin solution: Dissolve a pancreatin tablet (Oxoid) in $25 \mathrm{ml}$ sterile distilled water at $37^{\circ} \mathrm{C}$. Seitz filter the solution and store at $4^{\circ} \mathrm{C}$ for use within seven days. machine is run at an attenuation of $2 \times 10^{-2}$. The results are traced on to a linear chart recorder and compared with those obtained from a standard solution of fatty acids in water (Sepulco). Eradication of anaerobic bacteria is closely followed by the disappearance of fatty acids from clinical samples, and this may be of value in assessing the effectiveness of treatment.

A suitable broth medium for growing bacteria before GLC is as follows:

\begin{tabular}{|c|c|c|}
\hline & & \\
\hline & & \\
\hline Sodium Ic & suipioxyia & .03 \\
\hline Peptone & (Oxoid) & $1.00 \mathrm{~g}$ \\
\hline Yeast extract & (Oxoid) & $1.00 \mathrm{~g}$ \\
\hline Sodium chloride & & $\mathrm{g}$ \\
\hline Glucose & (Oxoid) & $1 \cdot$ \\
\hline L-cysteine hyd & & $0 \cdot($ \\
\hline Vitamin $\mathrm{K} /$ Hemin & (Sigma) & 1.0 \\
\hline Distilled water & 10 & 00 \\
\hline
\end{tabular}

The $\mathrm{pH}$ of the medium is adjusted to 7.0 and it is sterilised at $115^{\circ} \mathrm{C}$ for 15 minutes.

\section{Discussion}

Viable bacteria were isolated from all the samples of intracranial pus studied by de Louvois et al. (1977a) and Ingham et al. (1977). In direct contrast to all previous studies on unselected patients, a common feature of which have been reports of sterile pus ranging in incidence from $4 \%$ (McFarlan, 1943) to $62 \%$ (Kao, 1973), Liske and Weikers (1964), Morgan et al. (1973), and Samson and Clark (1973) suggested that sterile cultures are due to antibiotics administered before aspiration. This may well be so if no attempt is made to dilute out or to neutralise any antibacterial agents present as soon as the sample is aspirated. The finding that pus samples containing anaerobic bacteria may be rendered sterile if allowed to stand at room temperature overnight supports this hypothesis (de Louvois, 1978).

Samples should, therefore, be collected into a liquid anaerobic culture medium containing antibiotic inactivators. Recent work suggests that thiol broth may be superior to thioglycollate for this purpose (Griffiths and Shoesmith, 1977). If samples are transported to the laboratory in this way, then routine bacteriological procedures are satisfactory for the isolation of infecting bacteria.

Standard identification procedures are suitable for the majority of isolates. The viridans and non-haemolytic streptococci are best identified using the scheme of Colman and Williams (1972) and Colman (1976). Care needs to be taken to avoid confusion between carboxyphilic, microaerophilic, and anaerobic streptococci since many isolates of 
Streptococcus milleri only grow anaerobically on primary culture. Initial separation of the various groups of anaerobic Gram-negative rods may be achieved using selected high concentration antibiotic discs (Leigh, 1976).

The problem of establishing the role of anaerobic bacteria in intracranial sepsis is complicated by the fact that the organism described and recognised as Strep. milleri (Colman, 1970; Colman and Williams, 1972 ) is biochemically indistinguishable from that referred to as Peptostreptococcus intermedius in the earlier Virginia Polytechnic Handbook (Holdeman and Moore, 1972) and the API system for identification of anaerobic bacteria. Acetic acid and sometimes propionic acid are the only fatty acids found in the GLC profiles of $P$. intermedius (VPI Handbook) and of Strep. milleri (de Louvois, 1977). Neither of these organisms is a strict anaerobe, but both require additional carbon dioxide for growth.

GLC using Chromosorb 101 as the stationary phase has the advantage that samples do not have to be extracted. The demonstration of volatile fatty acids (butyric, caproic, valeric, etc) in $1 \mu \mathrm{l}$ crude pus can confirm the presence of anaerobic bacteria within 30 minutes of receiving the sample. The procedure, carried out on subsequent aspirates, may also provide useful information on the effectiveness of therapy on anaerobic bacteria.

Duffy (1969) pointed out the hazards of lumbar puncture in patients with intracranial abscess. Despite this, many patients do undergo lumbar puncture before referral and before an intracranial or intraspinal abscess has been recognised. Cerebrospinal fluid from such patients is usually bacteriologically sterile, and some will have normal cell counts, sugar, and protein (de Louvois, 1978). The isolation of an organism unlikely to cause uncomplicated meningitis or of a mixed bacterial population should alert the bacteriologist to the possibility of an intracranial abscess.

There is an association between the site of an abscess in the central nervous system, the proximate cause, and the types of microbes that are likely eventually to be isolated (de Louvois et al., 1977a, 1977b). Thus an early report on the Gram film of the original sample and of the GLC profile of the pus may provide useful therapeutic information, and the neurosurgeon should be informed of these as soon as possible. Initial therapy may have to be modified after presentation of definitive reports.

\section{References}

Bailey, R. W., and Oxford, A. E. (1958). Prerequisites for dextran production by Streptococcus bovis. Nature, 182, 185-186.
Colman, G. (1970). The classification of streptococcal strains. Ph.D. Thesis, University of London.

Colman, G. (1976). The viridans streptococci. In Selected Topics in Clinical Bacteriology, edited by J. de Louvois, Baillière Tindall, London, pp. 179-198.

Colman, G., and Williams, R. E. O. (1972). Taxonomy of some human viridans streptococci. In Streptococci and Streptococcal Diseases, edited by L. W. Wannamaker and J. M. Matsen, Academic Press, New York and London, pp. 282-299.

Cowan, S. T., and Steel, K. J. (1965). Manual for the Identification of Medical Bacteria, Cambridge University Press, Cambridge.

Duffy, G. P. (1969). Lumbar puncture in the presence of raised intracranial pressure. British Medical Journal, 1, 407-409.

Griffiths, J. L., and Shoesmith, J. G. (1977). Enhancement of the bactericidal effect of oxygen on obligate anaerobes by sodium thioglycollate. Proceedings of the Society for General Microbiology, 4, 145.

Hehre, E. J., and Neill, J. M. (1946). Formation of serologically reactive dextrans by streptococci from subacute bacterial endocarditis. Journal of Experimental Medicine, 83, 147-162.

Holdeman, L. V., and Moore, W. E. C. (1972). Anaerobic Laboratory Manual. Virginia Polytechnic Institute and State University Anaerobic Laboratory, Blacksburg, Virginia.

Ingham, H. R., Selkon, J. B., and Roxby, C. M. (1977). Bacteriological study of otogenic cerebral abscesses: chemotherapeutic role of metronidazole. British Medical Journal, 2, 991-993.

Kao, M. C. (1973). Brain Abscess: A clinical analysis of 26 cases with surgical treatment. Bulletin of the Tokyo Medical and Dental University, 20, 35-50.

Leigh, D. A. (1976). Bacteroides infections. In Selected Topics in Clinical Bacteriology, edited by J. de Louvois Baillière Tindall, London, pp. 129-177.

Liske, E., and Weikers, N. J. (1964). Changing aspects of brain abscesses: review of cases in Wisconsin 1940 through 1960. Neurology, Minneapolis, 14, 294-300.

de Louvois, J. (1977). Ph.D. Thesis, University of London. de Louvois, J. (1978). The bacteriology and chemotherapy of brain abscess. Journal of Antimicrobial Chemotherapy, 4, 395-413.

de Louvois, J., and Hurley, R. (1976). Antibiotic concentration in intracranial pus. Chemotherapy: Proceedings of the 9th International Congress of Chemotherapy, 1975, edited by J. D. Williams and A. M. Geddes, Vol. 4, pp. 61-70. Plenum Press, New York. de Louvois, J., and Hurley, R. (1977). Inactivation of penicillin by purulent exudates. British Medical Journal, 1, 998-1000.

de Louvois, J., Gortvai, P., and Hurley, R. (1977a). Bacteriology of abscesses of the central nervous system: a multicentre prospective study. British Medical Journal, 2, 981-984.

de Louvois, J., Gortvai, P., and Hurley, R. (1977b). Antibiotic treatment of abscesses of the central nervous system. British Medical Journal, 2, 985-987.

McFarlan, A. M. (1943). The bacteriology of brain abscess. British Medical Journal, 2, 643-644. 
Morgan, H., Wood, M. W., and Murphey, F. (1973). Experience with 88 consecutive cases of brain abscess. Journal of Neurosurgery, 38, 698-704.

Niven, C. F., Jr., Smiley, K. L., and Sherman, J. M. (1942). The hydrolysis of arginine by streptococci. Journal of Bacteriology, 43, 651-660.

Parker, M. T., and Ball, L. C. (1976). Streptococci and aerococci associated with systemic infection in man. Journal of Medical Microbiology, 9, 275-302.

Poole, P. M., and Wilson, G. (1976). Infection with minute-colony-forming $\beta$-haemolytic streptococci. Journal of Clinical Pathology, 29, 740-745.

Samson, D. S., and Clark, K. (1973). A current review of brain abscess. American Journal of Medicine, 54, 201-210.

Shaw, M. D. M., and Russell, J. A. (1975). Cerebellar abscess: a review of 47 cases. Journal of Neurology, Neurosurgery and Psychiatry, 38, 429-435.

Stevens, P., and Young, L. S. (1977). Simple method for elimination of aminoglycosides from serum to permit bioassay of other antimicrobial agents. Antimicrobial Agents and Chemotherapy, 12, 286-287.

Requests for reprints to: Dr J deLouvois, Department of Microbiology, Queen Charlotte's Hospital, Goldhawk Road., London W6 0XG, UK.

\section{Reports and Bulletins prepared by the Association of Clinical Biochemists}

The following reports and bulletins are published by the Association of Clinical Biochemists. They may be obtained from The Publishing Department, British Medical Journal (ACB Technical Bulletins), B.M.A. House, Tavistock Square, London WC1H 9JR. Overseas readers should remit by British Postal or Money Order.

SCIENTIFIC REVIEWS (price $£ 1 \cdot 00 / \$ 2.00$ each)

1 The assessment of thyroid function March 1971 F. V. FLYNN and J. R. HOBBS

2 Renal function tests suitable for clinical practice January 1972 F. L. MITCHELL, N. VEALL, and R. W. E. WATTS

3 Biochemical tests for the assessment of fetoplacental function May 1975 C. E. WILDE and R. E. OAKEY

4 Test of exocrine pancreatic function March 1977 A. H. GOWENLOCK

5 Assay of cholinesterase in clinical chemistry March 1979 ELSIE SILK, J. KING, and MARY WHITTAKER

TECHNICAL BULletins (price $£ 1 \cdot 00 / \$ 2.00$ each)

22 Bilirubin standards and the determination of bilirubin by manual and technicon AutoAnalyzer methods January 1971 BARBARA BILLING, RUTH HASLAM, and $\mathrm{N}$. WALD

23 Interchangeable cells for spectrophotometers and fluorimeters September 1971 s. S. BROWN and A. H. GOWENLOCK

24 Simple tests to detect poisons March 1972 B. W. MEADE et al.

25 Blood gas analysers May 1972 K. DIxON

26 Kits for enzyme activity determination September 1972 S. B. ROSALKI and D. TARLOW

27 Assessment of pumps suitable for incorporation into existing continuous flow analytical systems November 1972 A. FLECK et al.
28 Routine clinical measurements of transferrin in human serum September 1973 K. DIXON

29 Control materials for clinical biochemistry (5th edition) September 1973 J. F. STEVENS

30 Notes on the quality of performance of serum cholesterol assays September 1973 s. s. BROWN

31 Determination of uric acid in blood and in urine July 1974 R. W. E. WATTS

32 A survey of amino acid analysers readily available in the United Kingdom September 1974 J. E. CARLYLE and P.PURKISS

33 Definitions of some words and terms used in automated analysis November 1974 A. FLECK, R. ROBINSON, S. S. BROWN, and J. R. HOBBS

34 Measurement of albumin in the sera of patients January 1975 LINDA SLATER, P. M. CARTER, and J. R. HOBBS

35 Investigation of the validity of temperature correction factors for serum aspartate and alanine transaminases March 1975 s. B. ROSALKI et al.

36 Factors influencing the assay of creatinine November 1975 J. G. H. COOK

37 A survey of enzyme reaction rate analysers readily available in the United Kingdom July 1977 R. A. SAUNDERS and R. F. BURNS

38 Transport of specimens for clinical chemistry analysis November 1977 P. WILDING, J. F. ZILVA, and c. E. WIIDE

39 A scheme for the evaluation of diagnostic kits May 1978 P. H. LLOYD 